\title{
Sheep Production Systems and Breeding Practices for Selected Zones of Tigray, Northern Ethiopia
}

\author{
Kiflay Welday ${ }^{1,2^{*}}$, Mengistu Urge ${ }^{2}$, Solomon Abegaz ${ }^{3}$ \\ ${ }^{1}$ Department of Animal and Range Sciences, Jigjiga University, Jigjiga, Ethiopia \\ ${ }^{2}$ Schools of Animal and Range Sciences, Haramaya University, Dire Dawa, Ethiopia \\ ${ }^{3}$ Ethiopian Institute of Agricultural Research (EIAR), Addis Ababa, Ethiopia \\ Email: *weldaykflom807@gmail.com
}

How to cite this paper: Welday, K., Urge, M. and Abegaz, S. (2019) Sheep Production Systems and Breeding Practices for Selected Zones of Tigray, Northern Ethiopia. Open Journal of Animal Sciences, 9, 135-150. https://doi.org/10.4236/ojas.2019.91012

Received: November 19, 2018

Accepted: January 18, 2019

Published: January 21, 2019

Copyright ( 2019 by author(s) and Scientific Research Publishing Inc. This work is licensed under the Creative Commons Attribution International License (CC BY 4.0).

http://creativecommons.org/licenses/by/4.0/ (c) (i) Open Access

\begin{abstract}
A study was undertaken to identify the production system, breeding practices and major production constraints of common Tigray highland sheep in 16 rural kebelles from eight districts of Tigray Regional State. A total of 480 households ( 30 households for each rural kebelle) were selected purposively to collect data through personal observations and a detailed structured questionnaire. Mixed crop-livestock production system was the dominant farming system in all the study districts. The farmers kept a variety of livestock species including sheep, goats, cattle, chickens horse, donkeys and bee colony. Sheep, principally as source of income, meat for home consumption, production of manure and for socio cultural purposes, are commonly herded with other species in the open grazing fields by young boys in a family. Mating was generally uncontrolled. Body size, growth rate and adaptability were the major traits in selecting rams, whereas ewes were selected based on body size, twining ability and lambing interval. Majority of sheep across all districts are housed in structures known as Gebella which is built from stone and mud wall and tree/corrugated iron sheet roofing separated from the main family house. The major constraints hampering sheep production in the study areas were feed shortage (0.25), lack of capital (0.24), insufficient veterinary services $(0.2)$, limited grazing land (0.2), water scarcity $(0.06)$ and predators $(0.05)$ with index value indicated in parenthesis. In order to improve the productivity of sheep, it is important to involve farmers and other stockholders in addressing these constraints and designing breed improvement interventions, considering the overall farming and breeding practice of smallholders.
\end{abstract}

\section{Keywords}

Husbandry Practice, Production Constraints, Sheep production System 


\section{Introduction}

The demand for livestock products is increasing as a result of increased human population and relative growth in income. Hence, sustainability of livestock production is important to ensure continuous and sufficient availability of livestock products for the current and future generations. Ethiopia has diverse livestock species and breeds that are associated with the diverse agro-ecology of the country. Sheep is among the most important livestock species and dominantly found in the crop-livestock production system. Recent statistics show the presence of 30.7 million heads of sheep in the country [1]. At the farm level, sheep contribute up to 63 percent of the net cash income derived from livestock production in the mixed farming system [2]. The Northern part of the country is among the areas where smallholder farmers widely practice subsistence sheep production. Overall the productivity of the sheep as measured by off take and size of animals available for market is low. Improving the sheep productivity through improved management and breeding is required as this is crucial for both food security and sustainable development of small holder farmers.

Assessing the production system, indigenous knowledge of selection, management, identification of breeding goals, describing morphological characters and productivity level of the breed in their habitat are prerequisites to set up improvement programs at the smallholder and pastoral levels [3]. The objectives of this study were, therefore, to characterize the existing sheep production systems and breeding practice, and to identify major constraints that limit productivity of common Tigray highland sheep.

\section{Materials and Methods}

\subsection{Description of the Study Areas}

The study was conducted in eight districts belonging to four zones of Tigray Regional State. The districts include Atsbie-Wemberta, Wukro-keleteAwelaelo, Ganta-Afeshume, Degua-Tembien, Enderta, Mekelle area, Offla and Alamata (Figure 1), which were purposively selected based on the availability of common Tigray highland sheep and accessibility. The study area lies' within $12^{\circ} 20^{\prime}$ and $14^{\circ} 16^{\prime} \mathrm{N}$ latitude and $39^{\circ} 15^{\prime}$ and $39^{\circ} 45^{\prime}$ longitude. The mean annual temperature varies from $14^{\circ} \mathrm{C}$ to $22^{\circ} \mathrm{C}$ while the mean annual rainfall ranges from about 400 $\mathrm{mm}$ to around $970 \mathrm{~mm}$ [4]. The districts are situated in an altitude range of 1500 to 3200 m.a.s.l. The farming system in all of the selected districts is characterized by crop livestock mixed farming system. The major crops grown in the lower altitude areas are sorghum, Teff (Ergrostis abysinica) and Maize while wheat, beans, barley, pea, lentil, grass pea, chick pea, rarely linseed and other highland crops are common in the mid and highland areas.

\subsection{Sampling Techniques and Data Collection}

Two rural villages (kebelles) were selected purposively while households to be interviewed from each of the kebeles were randomly selected among the common 

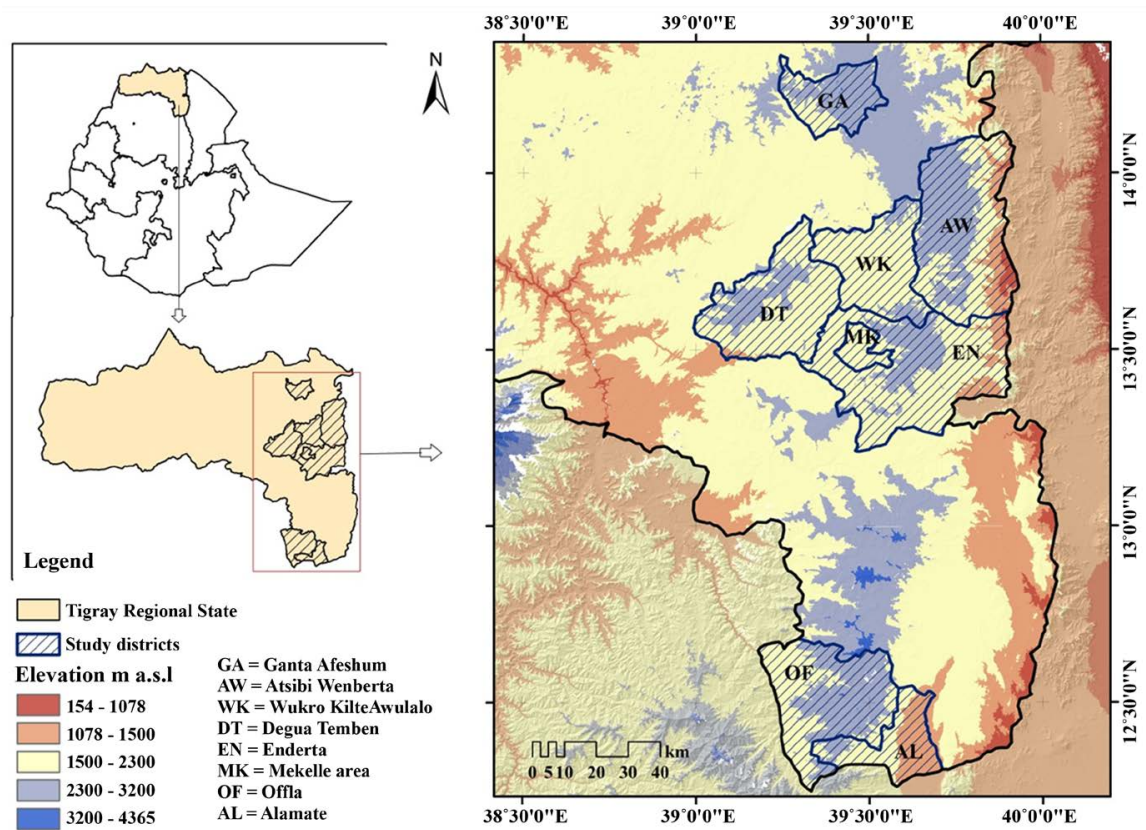

Figure 1. Location of the study areas.

Tigray highland sheep owners. Discussions were made with key informants such as farmers' representatives/elders and livestock experts in the Bureau of agriculture and rural development.

Data pertaining to common Tigray highland sheep were collected through a household survey. A total of 480 household heads (30 per rural kebelle) were randomly selected and interviewed using structured questionnaires developed from previous researcher [5]. Before conducting the formal survey, the questionnaire was pre tested and modified to match with the study area's livestock production system and for its appropriateness. The survey was carried out by enumerators under close supervision and participation of the researcher. From the field survey, information on general household characteristics, purposes of keeping sheep, common Tigray highland sheep flock structure, breeding system and selection criteria, disposal and acquisition of sheep were gathered and documented as per the questionnaires developed and pre-tested. The discussion made with the key informants were focused on collecting data pertaining to the production system and potential breeding tract of the common Tigray highland sheep breed.

\subsection{Data Analysis}

Statistical Package for Social Sciences (SPSS, Corp.21, Release, 2012 [6]) was used to analyze the survey data (household information, sheep husbandry and diseases management practice, feeding practice, purpose of sheep keeping, production constraints, selection criteria, acquiring and disposal of sheep), while data for land holding per-household, flock structure and reproductive performances were subjected to analysis of variance (ANOVA) using the general linear 
model procedure of SAS version 9.2 (2008 [7]). Tests of statistical significance or otherwise of particular mean comparisons were done with Duncan's multiple range test. Indices were calculated for all ranking data using the formula: Index $=\Sigma[3$ for rank $1+2$ for rank $2+1$ for rank 3$]$ given for an individual reason divided by $\Sigma$ [ 3 for rank $1+2$ for rank $2+1$ for rank 3] for all reasons where indices represent weighted averages of all rankings for a particular trait or reason $[8]$.

\section{Results and Discussion}

\subsection{Household Information}

Mixed crop-livestock production system is the dominant farming system in the study areas. Livestock production is subsistence-oriented and it is a traditional type which is characterized by minimal inputs like in the other parts of Ethiopia. It was demonstrated that low input production system is found in all livestock production systems prevailing in the country except in peri-urban and urban system [9]. Table 1 presents some key characteristics of the respondents across the study districts. The overall average age of the household head was $48.33 \pm$ 9.16 years, implying that the respondents were adults with a good experience in

Table 1. Background characteristics of the respondents in the study areas.

\begin{tabular}{|c|c|c|c|c|c|c|c|c|c|}
\hline \multirow[b]{2}{*}{$\begin{array}{l}\text { Descriptor } \\
\text { variables }\end{array}$} & \multicolumn{8}{|c|}{ Districts (Mean \pm SD) } & \multirow[b]{2}{*}{$\begin{array}{c}\text { Overall } \\
\text { mean } \\
\mathrm{N}=480\end{array}$} \\
\hline & $\begin{array}{l}\text { Alamata } \\
\mathrm{N}=60\end{array}$ & $\begin{array}{c}\text { Atsbie-Wemberta } \\
\qquad N=60\end{array}$ & $\begin{array}{l}\text { Degua-Tembien } \\
\qquad N=60\end{array}$ & $\begin{array}{l}\text { Enderta } \\
\mathrm{N}=60\end{array}$ & $\begin{array}{l}\text { Ganta-Afeshume } \\
\qquad N=60\end{array}$ & $\begin{array}{l}\text { Mekelle area } \\
\qquad \mathrm{N}=60\end{array}$ & $\begin{array}{c}\text { Offla } \\
\mathrm{N}=60\end{array}$ & $\begin{array}{c}\text { Wukro-kelete } \\
\text { Awelaelo } \\
\mathrm{N}=60\end{array}$ & \\
\hline Agen (years) & $47.5 \pm 10.3$ & $46.9 \pm 8.1$ & $47.2 \pm 8.85$ & $48.6 \pm 7.4$ & $51.4 \pm 9.1$ & $48.7 \pm 6.7$ & $48.0 \pm 9.3$ & $48.4 \pm 10.0$ & $48.3 \pm 9.2$ \\
\hline Family size & $7.6 \pm 3.5$ & $5.1 \pm 1.7$ & $6.2 \pm 2.4$ & $7.1 \pm 2.6$ & $6.7 \pm 2.4$ & $6.3 \pm 2.7$ & $6.6 \pm 2.6$ & $6.3 \pm 2.4$ & $6.5 \pm 2.7$ \\
\hline \multicolumn{10}{|c|}{ Sex (in Percent) } \\
\hline Male & 71.7 & 81.7 & 70.0 & 78.3 & 75.0 & 75.0 & 76.7 & 71.7 & 75.0 \\
\hline Female & 28.3 & 18.3 & 30.0 & 21.7 & 25.0 & 25.0 & 23.3 & 28.3 & 25.0 \\
\hline \multicolumn{10}{|c|}{ Educational Level (in Percent) } \\
\hline Illiterate & 45.0 & 30.0 & 30.0 & 38.3 & 30.0 & 16.7 & 46.7 & 26.7 & 32.6 \\
\hline Read \& write & 41.6 & 53.3 & 46.7 & 46.7 & 55.0 & 60.0 & 45.0 & 60.0 & 51.3 \\
\hline G $1-8$ & - & 10.0 & 15.0 & 6.7 & 6.7 & 11.3 & 5.0 & 3.3 & 7.3 \\
\hline G $9-10$ & 6.7 & 3.3 & 5.0 & 5.0 & 5.0 & 3.3 & 1.7 & 5.0 & 4.4 \\
\hline G $11-12$ & 6.7 & 3.3 & 3.3 & 3.3 & 3.3 & 8.3 & 1.7 & 5.0 & 4.4 \\
\hline Total & 100.0 & 100.0 & 100.0 & 100.0 & & 100.0 & 100.0 & 100.0 & 100.0 \\
\hline \multicolumn{10}{|c|}{ Religion (in Percent) } \\
\hline Orthodox & 91.7 & 100.0 & 98.3 & 98.3 & 96.7 & 93.3 & 78.3 & & 94.4 \\
\hline Muslim & 8.3 & 0.0 & 1.7 & 1.7 & 3.3 & 6.7 & 21.7 & 91.3 & 5.6 \\
\hline Total & 100.0 & 100.0 & 100 & 100.0 & 100.0 & 100.0 & 100.0 & 8.7 & 100.0 \\
\hline
\end{tabular}

$\mathrm{G}=$ Grade $\mathrm{N}=$ Number of interviewed households; $\mathrm{SD}=$ Standard Deviation . 
sheep farming. The overall mean family size was $6.49 \pm 2.65$, which is comparable with the estimation of 6.4 persons per household reported in other area [10]. Among the total household heads, $75.0 \%$ were males, which is comparable to the result reported by earlier researchers [11] [12]. Household headed by female in the present study is high, which could be attributed to the death of mainly males in the prolonged internal conflict during the Derg regime and border dispute between Eritrea and Ethiopia.

The majority of the respondents (94.4\%) were follower of Ethiopian Orthodox Christianity, while the remaining (5.6\%) were Muslims. The overall literacy rate among the household heads was $67.4 \%$. Small holder farmers close to the regional capital Mekelle have higher (82.9\%) while those in Alamata $(55.0 \%)$ and Offla (53.4\%) recorded lower literacy rate. This variation could be due to the distance to the urban centers, since education facilities in such areas are likely better for offering chance to the residents to educate themselves and their children. The presence of better educational background in this study would be a good opportunity for enhancing animal genetic improvement programs in the study areas, since literate communities are more likely better to adopt and practice new technologies and also to keep performances records of animals. The present findings indicate that sheep farming is performed by every social class of the community regardless of their background characteristics and show the significant importance of sheep to the producers.

\subsection{Land Holding and Farm Activities}

The overall average landholding per household in the study areas was $1.0 \pm 0.8$ hectare (Table 2). There is significant $(\mathrm{P}<0.05)$ difference between the districts. Alamata, Enderta and Mekelle area districts have larger land holding while households in Atsbie-Wemberta, Wukro-keleteAwelaelo, GantaAfeshume, Degua-Tembien and Offla have smaller landholding with no significant difference in land size among these districts. This result shows that the average land holding size per household in the mid altitude was higher than high altitude due to the dense population in the later. Almost all respondents across the study areas indicated that the trend of land holding size per household is decreasing over time. Human population growth rate, expansion of the existing town and newly established town, establishment of governmental institutes, land degradation and soil erosion are some of the mentioned factors contributing to the declining landholding per house hold across all districts. The average landholding reported in this study was greater than $0.5 \pm 0.53$ hectare reported for Atsbie-Wemberta district [11].

\subsection{Livestock Holding and Flock Structures}

There was a significant difference $(\mathrm{P}<0.05)$ in average number of sheep, goat, cattle, chicken, bee colony, donkey and horse across the districts (Table 2). Higher numbers of sheep were found in Mekelle area, Alamata, Enderta and Offla while 
Table 2. Small holder land holding and flock structure of the study areas (Mean \pm SD).

\begin{tabular}{|c|c|c|c|c|c|c|c|c|c|c|}
\hline \multirow[b]{2}{*}{ Descriptors } & \multicolumn{9}{|c|}{ Districts } & \multirow{2}{*}{$\begin{array}{c}\text { Test } \\
\text { P-value }\end{array}$} \\
\hline & $\begin{array}{c}\text { Alamata } \\
\mathrm{N}=60\end{array}$ & $\begin{array}{c}\text { Atsbie-Wemberta } \\
\qquad \mathrm{N}=60\end{array}$ & $\begin{array}{l}\text { Degua-Tembien } \\
\qquad N=60\end{array}$ & $\begin{array}{l}\text { Enderta } \\
\mathrm{N}=60\end{array}$ & $\begin{array}{c}\text { Ganta-Afeshume } \\
\qquad \mathrm{N}=60\end{array}$ & $\begin{array}{l}\text { Mekelle area } \\
\qquad \mathrm{N}=60\end{array}$ & $\begin{array}{c}\text { Offla } \\
\mathrm{N}=60\end{array}$ & $\begin{array}{l}\text { WKA } \\
\mathrm{N}=60\end{array}$ & $\begin{array}{l}\text { Overall } \\
\mathrm{N}=480\end{array}$ & \\
\hline $\begin{array}{c}\text { Average land } \\
\text { size/househol } \\
\text { d (ha) }\end{array}$ & 2.1 & $4^{\mathrm{d}}$ & d & $1.4 \pm$ & \pm 0.4 & & $0.8 \pm 0.6^{\mathrm{d}}$ & $0.7 \pm 0.5^{\mathrm{d}}$ & $1.0 \pm 0.8$ & $\mathrm{P}$ \\
\hline \multicolumn{11}{|l|}{ Livestock } \\
\hline Ram & $1.9 \pm 0.8^{\mathrm{a}}$ & $0.9 \pm 0.6^{c}$ & $1 \pm 0.5^{c}$ & $1.4 \pm 0.6^{\mathrm{b}}$ & $1.1 \pm 0.9^{c}$ & $1.8 \pm 1.1^{\mathrm{a}}$ & $1.5 \pm 0.9^{\mathrm{b}}$ & $1.0 \pm 0.8^{\mathrm{c}}$ & $1.3 \pm 0.8$ & $\mathrm{P}<0.00$ \\
\hline Ewe & $9.0 \pm 2.8^{\mathrm{a}}$ & $6.8 \pm 1.9^{\mathrm{cd}}$ & $5.5 \pm$ & $7.6 \pm 3.5^{\mathrm{bc}}$ & $6.3 \pm 1.8^{\mathrm{de}}$ & & $8.2 \pm 2.0^{\mathrm{ab}}$ & $6.2 \pm 1.6^{\mathrm{de}}$ & $7.3 \pm 1.6$ & $\mathrm{P}$ \\
\hline Ram lamb & $2.6 \pm 1.0^{\mathrm{b}}$ & $2.2 \pm 0.8^{\mathrm{bc}}$ & $1.9 \pm 0.8^{\mathrm{c}}$ & $2.6 \pm 1.1^{\mathrm{b}}$ & $2.2 \pm 0.9^{\mathrm{bc}}$ & $3.5 \pm 1.8^{\mathrm{a}}$ & $2.7 \pm 1.2^{\mathrm{b}}$ & $2.2 \pm 0.9^{\mathrm{bc}}$ & $2.5 \pm 0.9$ & $\mathrm{P}<0.0$ \\
\hline Ewe lamb & $2.9 \pm 1.1^{\mathrm{bc}}$ & $2.6 \pm 0.8^{\mathrm{bcd}}$ & $2.3 \pm 0.6^{\mathrm{d}}$ & $3.5 \pm 1.9^{\mathrm{a}}$ & $2.4 \pm 1.0^{\mathrm{cd}}$ & & $3.0 \pm 1.2^{\mathrm{b}}$ & $2.5 \pm 1.1^{\mathrm{cd}}$ & $2.8 \pm 1.1$ & $\mathrm{P}<0.0$ \\
\hline Sheep & $16.3 \pm 3.9^{\mathrm{a}}$ & $12.5 \pm 2.4^{\mathrm{c}}$ & $10.7 \pm 2.4^{\mathrm{d}}$ & $15.1 \pm 5.0^{\mathrm{b}}$ & $11.9 \pm 3.1^{\mathrm{cd}}$ & $17.5 \pm 6.0^{\mathrm{a}}$ & $15.3 \pm 3.8^{\mathrm{b}}$ & $11.9 \pm 2.9^{c d}$ & d $13.9 \pm 4.5$ & $5 \mathrm{P}<0.00$ \\
\hline Goats & $9.2 \pm 2.5^{\mathrm{a}}$ & $2.8 \pm 2.3^{\mathrm{e}}$ & $4.0 \pm 2.3^{\mathrm{d}}$ & $7.9 \pm 2.7^{\mathrm{b}}$ & $4.9 \pm 2.3^{c}$ & $8.0 \pm 2.1^{\mathrm{b}}$ & $5.1 \pm 3.2^{\mathrm{c}}$ & $5.2 \pm 2.2^{\mathrm{c}}$ & $5.9=$ & $\mathrm{P}<0.00$ \\
\hline Cattle & $5.5 \pm 3.7^{\mathrm{cde}}$ & $4.5 \pm 2.1^{\mathrm{e}}$ & $4.5 \pm 2.3^{\mathrm{e}}$ & $6.4 \pm 2.2^{\mathrm{bc}}$ & $6.1 \pm 1.5^{\mathrm{bcd}}$ & $7.0 \pm 2.2^{\mathrm{b}}$ & $9.3 \pm 4.4^{\mathrm{a}}$ & $5.3 \pm 1.5^{\mathrm{de}}$ & $6.1 \pm 3.0$ & $\mathrm{P}<0.00$ \\
\hline Chicken & $12.8 \pm 4.6^{\mathrm{a}}$ & $10.5 \pm 2.5^{\mathrm{b}}$ & $10.4 \pm 3.1^{\mathrm{b}}$ & $8.4 \pm 3.3^{\mathrm{c}}$ & $10.5 \pm 2.6^{\mathrm{b}}$ & $10.3 \pm 3.9^{\mathrm{b}}$ & $10.2 \pm 4.5^{\mathrm{b}}$ & $9.1 \pm 3.5^{\mathrm{bc}}$ & $10.3 \pm 3.8$ & $8 \mathrm{P}<0.00$ \\
\hline Bee colony & $0.9 \pm 1.1^{\mathrm{d}}$ & $2.1 \pm 1.2^{\mathrm{b}}$ & $3.1 \pm 1.7^{\mathrm{a}}$ & $1.4 \pm 1.1^{\mathrm{c}}$ & $1.9 \pm 1.0^{\mathrm{b}}$ & $1.4 \pm 0.9^{c}$ & $0.9 \pm 0.9^{\mathrm{d}}$ & $1.1 \pm 1.3^{\mathrm{cd}}$ & $1.6 \pm 1.4$ & $\mathrm{P}<0.00$ \\
\hline Donkey & $1.1 \pm 0.7^{\mathrm{bc}}$ & $1.0 \pm 0.5^{\mathrm{c}}$ & $0.9 \pm 0.5^{c}$ & $1.5 \pm 0.6^{\mathrm{a}}$ & $1.1 \pm 0.7^{\mathrm{bc}}$ & $1.3 \pm 0.7^{\mathrm{ab}}$ & $1.1 \pm 0.8^{\mathrm{bc}}$ & $1.0 \pm 0.5^{\mathrm{c}}$ & $1.1 \pm 0.7$ & $\mathrm{P}<0.00$ \\
\hline Horse & $0.0 \pm 0.0^{\mathrm{d}}$ & $0.6 \pm 0.7^{\mathrm{ab}}$ & $0.4 \pm 0.6^{b c}$ & $0.4 \pm 0.5^{b c}$ & $0.7 \pm 0.7^{\mathrm{a}}$ & $0.3 \pm 0.5^{c}$ & $0.8 \pm 0.8^{\mathrm{a}}$ & $0.4 \pm 0.5^{b c}$ & $0.4 \pm 0.6$ & $\mathrm{P}<0.0$ \\
\hline
\end{tabular}

${ }^{\text {a-e }}$ Means with in a row with different superscripts $\operatorname{differ}(\mathrm{P}<0.05)$; ha $=$ hectare; $\mathrm{N}=$ Number of respondents; $\mathrm{SD}=\mathrm{Standard}$ deviation, $\mathrm{WKA}=\mathrm{Wu}-$ kro-keleteAwelaelo. 
Table 3. Distribution of households according to their sheep housing systems and herd managements across eight districts.

\begin{tabular}{|c|c|c|c|c|c|c|c|c|c|}
\hline \multirow[b]{2}{*}{ Variables } & \multicolumn{8}{|c|}{ Respondents (\%) by Districts } & \multirow[b]{2}{*}{$\begin{array}{l}\text { Overall } \\
\mathrm{N}=480\end{array}$} \\
\hline & $\begin{array}{c}\text { Alamata } \\
\mathrm{N}=60\end{array}$ & $\begin{array}{c}\text { Atsbie-Wemberta } \\
\qquad \mathrm{N}=60\end{array}$ & $\begin{array}{c}\text { Degua-Tembien } \\
\qquad N=60\end{array}$ & $\begin{array}{c}\text { Enderta } \\
\mathrm{N}=60\end{array}$ & $\begin{array}{c}\text { Ganta-Afeshume } \\
\mathrm{N}=60\end{array}$ & $\begin{array}{l}\text { Mekelle area } \\
\qquad \mathrm{N}=60\end{array}$ & $\begin{array}{c}\text { Offla } \\
\mathrm{N}=60\end{array}$ & $\begin{array}{c}\text { Wukro-kelete } \\
\text { Awelaelo } \\
\mathrm{N}=60\end{array}$ & \\
\hline Closed & 56.67 & 90.0 & 90 & 16.67 & 78.3 & 30.0 & 90.0 & 63.3 & 64.38 \\
\hline Open & 5.00 & - & - & 3.33 & - & 20.0 & 1.7 & 18.3 & 29.58 \\
\hline Semi-closed & 38.33 & 10.0 & 10 & 80.00 & 21.7 & 50.0 & 8.3 & 18.3 & 6.04 \\
\hline \multicolumn{10}{|c|}{ Herding practice during day time } \\
\hline All in one & 85.00 & 80.0 & 80.0 & 70.00 & 75.0 & 58.3 & 86.7 & 80.0 & 76.67 \\
\hline Separate by age & - & - & - & 18.33 & - & 21.7 & - & - & 5.21 \\
\hline Separate by species & 15.00 & 20.0 & 20.0 & 11.67 & 25.0 & 20.0 & 13.3 & 20.0 & 18.13 \\
\hline \multicolumn{10}{|c|}{ Housing practice during night time } \\
\hline All in one & 35.00 & 33.3 & 35.0 & 58.33 & 36.7 & 50.0 & 63.3 & 50.0 & 45.21 \\
\hline Separate by age & 26.67 & 25.0 & 16.7 & 20.00 & 30.0 & 21.7 & 11.7 & 16.7 & 21.04 \\
\hline Separate by species & 38.33 & 41.7 & 48.3 & 21.67 & 33.3 & 28.3 & 25.0 & 33.3 & 33.75 \\
\hline
\end{tabular}

$\mathrm{N}=$ Number of Respondents.

house termed locally as (Gebella) which is constructed from stone and locally available timber. All classes of the sheep were herded together during the day time though new born lambs were kept separately the first few days near the village and around the residence house of the owners. Higher percentage of respondents (80\% to $85 \%)$, in Alamata, Atsbie-Wemberta, Degua-Tembien, Offla and Wukro-keleteAwelaelo keep their sheep in mixed herd along with cattle, goat and equines (Table 3). There is a mixing with other adjacent sheep flocks within a village immediately after crops are harvested (September to November) during communal grazing of crop aftermath. About $45.21 \%$, 33.75\% and $21.04 \%$ of the respondents keep their sheep during the night either together with other species or separate by species or separate by age group, respectively.

\subsubsection{Feed Resources and Feeding Practice}

The major feed sources for sheep in the eight districts are summarized in Table 4. Natural pasture, crop residue, crop aftermath, hay, atella (by product from traditional brew) and concentrate are the major feed sources in all the study areas. Among these feed resources, Natural pasture contributes the largest proportion followed by crop residue in all districts. The contribution of green grasses to feed farm animals is limited by the short duration of the rainfall. However, crop aftermath is replaced by grazing on common grazing land in those areas during the dry season. There was no improved forage introduced in all study sites. Sheep generally graze the whole day and taken to water sites (rivers and streams) once a day or three to four times a week. Sorghum straw and browse plants 
Table 4. Feed resources of the study areas.

\begin{tabular}{ccccc}
\hline \multirow{2}{*}{ Feed Resources } & \multicolumn{3}{c}{ Ranks } & Index \\
\cline { 2 - 5 } & $1^{\text {st }}$ & $2^{\text {nd }}$ & $3^{\text {rd }}$ & \\
\hline Natural Pasture & 285 & 95 & 37 & 0.376 \\
Crop residue & 84 & 112 & 111 & 0.204 \\
Crop aftermath & 67 & 123 & 100 & 0.190 \\
Hay & 21 & 56 & 66 & 0.084 \\
Concentrate & 14 & 44 & 63 & 0.067 \\
Brewery by products & 5 & 17 & 26 & 0.026 \\
Atella & 4 & 23 & 58 & 0.040 \\
Cactus & 0 & 10 & 19 & 0.014 \\
\hline
\end{tabular}

dominated by Acacia species and other thorny plants are the predominant feed sources in Alamata, Enderta, Mekelle and Wukro-keleteAwelaelo districts. While Natural pasture lands and residues from cereal "Teff" (Eragrostis abysinica), wheat, and barley are the major feed sources in Atsbie-Wemberta, Degua-Tembien, Ganta-Afeshume and Offla. The available feed has poor nutritive value and is less palatable during most of the year. Moreover, sheep and goat are left to graze and browse alongside with large animals that even worsen the feed shortage as animals need to compete with each other.

\subsubsection{Common Sheep Diseases and Health Management}

Based on the results of the interview, group discussion and observations made, sheep pox, Coenurosis, Pasturellosis, External Parasites Foot and Mouth diseases, Anthrax, Foot rot and Respiratory diseases were the major diseases which affect sheep production in the study areas. Although vaccination was provided, it is limited to few common diseases. Limited animal health service delivery has been reported by sheep owners in all study areas (Table 5).

\subsection{Sheep Production Constraints}

The results indicate that feed and grazing land shortages, income, disease, water scarcity and loss of sheep by predators were the major constraints affecting sheep production (Table 6). Among these constraints feed shortage, income and diseases were top three constraints across the districts. Similar feed shortage is reported in different area [17]. Feed shortage especially in the long dry season is critical problem in all study sites. This factor extremely affects the growth rate and body energy reserve of animals rendering them to have a low quality meat [18].

Proper feeding with high-energy diets increases the meat quality through increasing the muscle glycogen reserve, which helps to keep the $\mathrm{pH}$ low after rigor mortis, and improve intramuscular fat content [19]. Therefore, proper feeding of animals for growth and meat quality should be practiced carefully. 
Table 5. Local names and scientific equivalents of the common sheep diseases in the study areas.

\begin{tabular}{|c|c|c|c|c|c|c|c|c|c|c|}
\hline \multicolumn{3}{|c|}{ Common sheep diseases } & \multicolumn{6}{|c|}{ Frequency of diseases per districts (Respondents in percentage) } & \multirow[b]{2}{*}{$\begin{array}{c}\text { Wukro-kelete } \\
\text { Awelaelo } \\
\mathrm{N}=60\end{array}$} & \multirow[b]{2}{*}{$\begin{array}{l}\text { Over all } \\
\mathrm{N}=480\end{array}$} \\
\hline Scientific name & $\begin{array}{c}\text { Local name } \\
\text { (Tigrigna) }\end{array}$ & $\begin{array}{c}\text { Alamata } \\
\mathrm{N}=60\end{array}$ & $\begin{array}{c}\text { Atsbie- } \\
\text { Wemberta } \\
\mathrm{N}=60\end{array}$ & $\begin{array}{l}\text { Degua- } \\
\text { Tembien } \\
\mathrm{N}=60\end{array}$ & $\begin{array}{c}\text { Enderta } \\
\mathrm{N}=60\end{array}$ & $\begin{array}{c}\text { Ganta-Afeshume } \\
\mathrm{N}=60\end{array}$ & $\begin{array}{c}\text { Mekelle area } \\
\quad \mathrm{N}=60\end{array}$ & $\begin{array}{c}\text { Offla } \\
\mathrm{N}=60\end{array}$ & & \\
\hline Anthrax & Megerem & 3.33 & 5.0 & 5.0 & 5.0 & 5.0 & 6.67 & 5.0 & 3.33 & 4.79 \\
\hline Coenurosis & Zartie & 3.33 & 20.0 & 13.33 & 5.0 & 20.0 & 6.67 & 20.0 & 11.67 & 12.50 \\
\hline Ticks & Kuridid & 26.67 & 23.33 & 31.67 & 30.0 & 18.33 & 25.0 & 26.67 & 20.0 & 25.21 \\
\hline Internal Parasite & Efeal & 16.67 & 20.0 & 16.67 & 11.67 & 23.33 & 13.33 & 20.0 & 10.0 & 16.46 \\
\hline Foot and Mouth & Eichlam & 16.67 & 6.67 & 8.33 & 20.0 & 6.67 & 16.67 & 5.0 & 21.67 & 12.70 \\
\hline Foot rot & Mojelle & 26.67 & 11.67 & 10.0 & 20.0 & 8.33 & 23.33 & 10.0 & 23.33 & 16.67 \\
\hline Pasteurelossis & Mi'eat & 3.33 & 8.33 & 11.67 & 5.0 & 13.33 & 5.0 & 8.33 & 6.67 & 7.71 \\
\hline Small pox & Enfrir & 3.33 & 5.00 & 3.33 & 3.33 & 5.0 & 3.33 & 5.0 & 3.33 & 3.96 \\
\hline
\end{tabular}

$\mathrm{N}=$ Number of respondents.

Table 6. Ranked sheep production constraints in the study areas.

\begin{tabular}{ccccc}
\hline \multirow{2}{*}{ Constraints } & \multicolumn{3}{c}{ Ranks } & Index \\
\cline { 2 - 5 } & $1^{\text {st }}$ & $2^{\text {nd }}$ & $3^{\text {rd }}$ & \\
\hline Feed shortage & 155 & 98 & 59 & 0.25 \\
Income & 103 & 108 & 166 & 0.24 \\
Shortage of grazing land & 85 & 124 & 73 & 0.2 \\
Diseases & 87 & 103 & 116 & 0.2 \\
water scarcity & 27 & 19 & 41 & 0.06 \\
Predators & 23 & 28 & 25 & 0.05 \\
\hline
\end{tabular}

\subsection{Sheep Production Objectives}

Table 7 shows the purpose of keeping sheep and their respective rank for the study area. Better understanding of the purposes of keeping sheep is a prerequisite for defining breeding goals [20]. Primary reason for keeping sheep in all study areas was income generation. Other reasons mentioned by farmers according to order of their respective indices were breeding purpose (stock replacement), home meat consumption, social security, holiday ceremony and manure.

Group discussion revealed that sheep rearing for income generation and household meat consumption were common and contribute to livelihood in the study areas, especially as alternative income sources to the poor. Given the breadth of purposes that farmers have for keeping sheep, much care is required in the choice of breeding objectives and breeding strategies as the function of the animals is closely linked to the traits desired by the producers [21]. Knowledge of reasons for keeping animals is a prerequisite for deriving operational breeding goals [20]. 
Table 7. Sheep production objectives in the study areas.

\begin{tabular}{ccccc}
\hline \multirow{2}{*}{ Production objectives } & \multicolumn{3}{c}{ Ranks } & Index \\
\cline { 2 - 4 } & Rank 1 & Rank 2 & Rank 3 & \\
\hline Income & 188 & 98 & 50 & 0.281 \\
Breeding & 104 & 159 & 67 & 0.242 \\
Meat for home consumption & 67 & 86 & 148 & 0.181 \\
Manure & 29 & 27 & 48 & 0.066 \\
Social Security & 58 & 86 & 109 & 0.158 \\
Holiday day ceremony & 34 & 26 & 58 & 0.074 \\
\hline
\end{tabular}

\subsection{Sheep Breeding Practice and Selection Criteria}

In the study areas, mating was random. There was no report of controlled mating system across the study areas. Rams run together with ewe throughout the year and castration was an uncommon practice, which leads to indiscriminate and uncontrolled breeding. Farmers who had no breeding males, purchase ram from local markets or got ram service from their neighbors. This finding is in line with previous findings [22] [23].

Selection criteria for ram and ewe with corresponding index values are presented in Table 8 . The respondents prioritized body size, growth rate and adaptability as selection criteria for ram with the indices of $0.38,0.26$ and 0.14 , respectively. The most important selection criteria for ewe were twining ability (index $=0.298$ ), body size (index $=0.258$ ) and lamb growth ability (index $=0.2$ ). Others like mothering ability, color, lambing interval and age at first sexual maturity were also reported as criteria but with lower rankings. This finding is comparable to that noted earlier [24]. Small holder farmers in all study districts indicated that they are mostly interested in getting more money when they sell live animals. The farmers wanted animals that grow fast, with higher mature weight, and preferably with high twinning rate with expectation to sell more animals per year.

\subsection{Reproductive Performances}

The results on reproductive performance are presented in Table 9. Good reproductive performance is a prerequisite for any successful livestock production program. Previous study suggested that differences exist in reproductive performance among indigenous sheep breeds and their variation allow for the selection of suitable breeds for a given environment [25].

\section{Age at first mating (sexual maturity)}

As indicated in Table 9, there is statistically significant difference $(\mathrm{p}<0.05)$ of age at first mating (sexually maturity) for both sexes across the study sites. Sheep reared at Offla, Enderta and Alamata achieve sexual maturity early as compared to those found in Mekelle, Degua-Tembien, Atsbie-Wemberta, Wukro-keleteAwelaelo and Ganta-Afeshume districts, which could be due to access to feed. The average 
Table 8. Selection criteria for ram and ewe in the study areas as ranked by owners.

\begin{tabular}{|c|c|c|c|c|}
\hline \multirow[t]{2}{*}{ Class and selection criteria's } & \multicolumn{3}{|c|}{ Ranks } & \multirow{2}{*}{ Index } \\
\hline & $1^{\mathrm{st}}$ & $2^{\text {nd }}$ & $3^{\text {rd }}$ & \\
\hline \multicolumn{5}{|l|}{ Ram } \\
\hline Body size (appearance) & 238 & 139 & 112 & 0.383 \\
\hline Growth rate & 98 & 193 & 77 & 0.263 \\
\hline Adaptability & 52 & 51 & 154 & 0.143 \\
\hline Age & 16 & 12 & 24 & 0.033 \\
\hline Horn condition & 26 & 27 & 39 & 0.059 \\
\hline Color & 45 & 46 & 57 & 0.099 \\
\hline Libido & 5 & 12 & 17 & 0.019 \\
\hline Over all & 480 & 480 & 480 & 1.000 \\
\hline \multicolumn{5}{|l|}{ Ewe } \\
\hline Body size (Appearance) & 143 & 115 & 83 & 0.258 \\
\hline Twining ability & 152 & 150 & 103 & 0.298 \\
\hline Lambing Interval & 26 & 22 & 9 & 0.045 \\
\hline Mothering ability & 22 & 24 & 31 & 0.050 \\
\hline Lamb growth & 77 & 103 & 135 & 0.200 \\
\hline Age at first sexual maturity & 28 & 32 & 65 & 0.074 \\
\hline Color & 32 & 34 & 54 & 0.076 \\
\hline Overall & 480 & 480 & 480 & 1.00 \\
\hline
\end{tabular}

Table 9. Reproductive performances of Common Tigray high-land sheep in the study areas.

\begin{tabular}{|c|c|c|c|c|c|c|c|c|c|c|}
\hline \multirow[t]{2}{*}{ Parameters } & \multicolumn{8}{|c|}{ Districts (Mean \pm SE) } & \multirow[b]{2}{*}{$\begin{array}{l}\text { Overall } \\
\mathrm{N}=480\end{array}$} & \multirow[b]{2}{*}{$\mathrm{P}$-value } \\
\hline & $\begin{array}{l}\text { Alamata } \\
\mathrm{N}=60\end{array}$ & $\begin{array}{c}\text { Atsbie- } \\
\text { Wemberta } \\
\mathrm{N}=60\end{array}$ & $\begin{array}{c}\text { Degua } \\
\text { Tembien } \\
\mathrm{N}=60\end{array}$ & $\begin{array}{l}\text { Enderta } \\
\mathrm{N}=60\end{array}$ & $\begin{array}{c}\text { Ganta } \\
\text { Afeshume } \\
\mathrm{N}=60\end{array}$ & $\begin{array}{c}\text { Mekelle area } \\
\qquad \mathrm{N}=60\end{array}$ & $\begin{array}{c}\text { Offla } \\
\mathrm{N}=60\end{array}$ & $\begin{array}{c}\text { WKA } \\
\mathrm{N}=60\end{array}$ & & \\
\hline $\begin{array}{l}\text { MAASM } \\
\text { (months) }\end{array}$ & $6.9 \pm 0.21^{\mathrm{d}}$ & $8.0 \pm 0.12^{b c}$ & $7.7 \pm 0.15^{c}$ & $6.8 \pm 0.11^{\mathrm{de}}$ & $9.0 \pm 0.18^{\mathrm{a}}$ & $7.5 \pm 0.09^{c}$ & $6.4 \pm 0.18^{\mathrm{e}}$ & $8.3 \pm 0.08^{b}$ & $7.5 \pm 0.66$ & $<0.001$ \\
\hline $\begin{array}{l}\text { FAASM } \\
\text { (months) }\end{array}$ & $6.1 \pm 0.16^{\mathrm{f}}$ & $9.5 \pm 0.19^{b}$ & $8.0 \pm 0.19^{c d}$ & $8.5 \pm 0.16^{c}$ & $7.9 \pm 0.21^{\mathrm{d}}$ & $8.5 \pm 0.13^{c}$ & $7.1 \pm 0.23^{\mathrm{e}}$ & $11.0 \pm 0.08^{\mathrm{a}}$ & $8.3 \pm 0.09$ & $<0.001$ \\
\hline $\begin{array}{c}\text { ALI } \\
\text { (months) }\end{array}$ & $8.8 \pm 0.14^{\mathrm{a}}$ & $8.0 \pm 0.13^{\mathrm{cd}}$ & $8.3 \pm 0.17^{\mathrm{bc}}$ & $8.6 \pm 0.15^{\mathrm{ab}}$ & $8.4 \pm 0.12^{\mathrm{bc}}$ & $6.9 \pm 0.15^{\mathrm{f}}$ & $7.3 \pm 0.13^{\mathrm{e}}$ & $7.8 \pm 0.10^{\mathrm{d}}$ & $8.0 \pm 0.05$ & $<0.001$ \\
\hline $\begin{array}{l}\text { ARLT } \\
\text { (years) }\end{array}$ & $11.0 \pm 0.16^{\mathrm{a}}$ & $9.2 \pm 0.14^{\mathrm{c}}$ & $9.7 \pm 0.27^{\mathrm{b}}$ & $7.6 \pm 0.15^{\mathrm{e}}$ & $9.9 \pm 0.22^{\mathrm{b}}$ & $10.8 \pm 0.09^{\mathrm{a}}$ & $8.6 \pm 0.12^{\mathrm{d}}$ & $9.8 \pm 0.17^{\mathrm{b}}$ & $9.6 \pm 0.08$ & $<0.001$ \\
\hline $\begin{array}{c}\text { AAW } \\
\text { (months) }\end{array}$ & $3.1 \pm 0.03^{\mathrm{b}}$ & $3.0 \pm 0.03^{b c}$ & $3.1 \pm 0.04^{b c}$ & $3.2 \pm 0.17^{\mathrm{ab}}$ & $3.0 \pm 0.01^{\mathrm{bc}}$ & $3.0 \pm 0.03^{b c}$ & $2.9 \pm 0.03^{c}$ & $3.4 \pm 0.03^{\mathrm{a}}$ & $3.1 \pm 0.02$ & $<0.001$ \\
\hline $\begin{array}{l}\text { MMAA } \\
\text { (months) }\end{array}$ & $10.6 \pm 0.07^{\mathrm{c}}$ & $10.7 \pm 0.17^{\mathrm{c}}$ & $11.9 \pm 0.52^{\mathrm{a}}$ & $11.6 \pm 0.15^{\mathrm{ab}}$ & $11.1 \pm 0.15^{\mathrm{bc}}$ & $9.2 \pm 0.20^{\mathrm{d}}$ & $10.9 \pm 0.32^{b c}$ & $11.6 \pm 0.11^{\mathrm{ab}}$ & $10.9 \pm 0.09$ & $<0.001$ \\
\hline
\end{tabular}

${ }^{\mathrm{a}-\mathrm{f}}$ Means with in a row with different superscripts differ significantly $(\mathrm{P}<0.05)$; ARLT = Average Reproductive life time; ALI = Average Lambing Interval; AAW = Average Age at weaning; FAASM = Female Average Age at sexual Maturity; MAASM = Male Average Age at Sexual maturity; MMAA = Male Market Average Age; $\mathrm{N}=$ Number of respondents; $\mathrm{SE}=$ Standard Error, WKA = Wukro-keleteAwelaelo. 
age sexual maturity recorded in the present study for male (7.5 \pm 0.7 months) and females ( $8.3 \pm 0.09$ months) is comparable to result reported by other authors [26].

\section{Lambing interval (LI)}

Lambing interval is the period between two consecutive parturitions that determines reproductive efficiency in sheep production. The lambing interval recorded for Alamata, Atsbie-wemberta, Degua-Tembien, Enderta, Ganta-Afeshume, Mekelle area, Offla and Wukro-keleteAwelaelo is slightly higher than $6.5 \pm 0.7$ reported for Tigray highland sheep [11] and $6.63 \pm 0.19$ for indigenous sheep population found in Eastern Ethiopia [27] under mixed crop livestock production system. Mekelle area, Offla, Wukro-keleteAwelaelo and Atsbie-Wemberta have lower lambing interval compared to Degua-Tembien, Ganta-Afeshume, Enderta and Alamata since the lambing interval is reasonable low, the possibility of three lambs within two years mainly depends on the availability of feed and improved management.

\section{Age at weaning}

All farmers across the study sites practiced natural weaning without intervention to stop suckling. The overall reported average weaning ages for both sexes was $3.1 \pm 0.02$ months, with a range of $2.9 \pm 0.03$ in Offla to $3.4 \pm 0.03$ months in Wukro-keleteAwelaelo. This range was on towards the middle lower end of 3 - 4 months reported for indigenous sheep breeds of Ethiopia [28] and lower than $3.9 \pm 0.9$ months for Gumuz sheep [29]. There is limited information for reproductive performance of indigenous sheep breeds in northern Ethiopia. The possible reasons for lower weaning age may be due to short lactating period which could be likely attributed to the low quality and quantity of feeds.

\section{Ewe Lifespan (longevity)}

The average reproductive life of the ewes in the study sites showed significant difference $(\mathrm{P}<0.05)$ among districts (Table 9). Among the eight study districts longer ewe life span $(11.0 \pm 0.13$ years) was recorded for Alamata sheep. Similar length of ewe life time span was noted for Bonga sheep [30]. Shorter life span of ewe (7.6 \pm 0.15 years) was found for sheep in Enderta district which is comparable to value reported [11].

Selling of ewes is not a common practice and ewes are rather reared for breeding purposes. But, males are sold at early age particularly during the holy days and festivals.

\subsection{Sheep Acquiring and Disposal Methods}

The commonest methods used to acquire sheep were birth on the farm, buying and gift in the order of listed (Table 10). Farmers across the study sites sell their animals when they face financial problems; primarily in the nearby markets where local traders are principally actors in the marketing process. The study results also indicated that higher numbers of sheep are sold and better price is fetched during holidays, although farmers sell sheep at any time of the year depending on their need for money. Sheep owners sold their sheep primarily to 
Table 10. Ways of acquiring and disposing sheep in the study areas as ranked by owners.

\begin{tabular}{ccccc}
\hline Way of acquiring and disposing sheep & \multicolumn{3}{c}{ Ranks } & \multicolumn{2}{c}{ Index } \\
\hline & Rank 1 & Rank 2 & Rank 3 & \\
\hline Way of sheep acquiring & & & & \\
Birth & 307 & 173 & 145 & 0.490 \\
Bought & 155 & 277 & 214 & 0.428 \\
Gift & 18 & 30 & 121 & 0.082 \\
Way of Disposing & & & & \\
Sale & 231 & 127 & 59 & 0.349 \\
Slaughter & 111 & 182 & 117 & 0.283 \\
Death & 98 & 103 & 215 & 0.2483 \\
Predators & 40 & 68 & 89 & 0.120 \\
\hline
\end{tabular}

purchase food items, cover health, farm input (fertilizer and cropland rent), labor (herdsman and laborers) and school expenses for children and to pay back credit.

Sheep marketing in the study areas were traditional type. All of the respondents reported that weighing balance is unknown for selling and/or buying animals; rather visual assessment was used to estimate body weight and condition of the animals and set a price. Hence, selling price was fixed by negotiation between sellers and buyers. This result is in agreement with many research reports [31] [32]. Generally, smallholder farmers dispose their sheep mainly through sale and slaughter for home use.

\section{Conclusion}

Sheep in the study area were principally bred as source of income, meat for home consumption, manure, cultural and ceremonial purposes. Body size, growth rate, adaptability and twining abilities were important functional traits for sheep selection in all study sites. The practice of uncontrolled mating may result into inbreeding; however, the mixing of flocks during communal grazing, or in the neighborhood during day time helps to reduce risk of inbreeding. The sheep are kept under traditional production system which is constrained by, shortage of feed and grazing land, diseases, water scarcity, frequent drought, predators, and poor veterinary service. The level of productivity is low and less attention is given to husbandry and breed improvement. In order to raise productivity it is important to involve farmers and other stockholders in designing breed improvement interventions, considering the existing breeding practices, management systems and trait preferences of the community and the multipurpose roles of sheep.

\section{Acknowledgements}

The authors would like to acknowledge farmers for their willingness to share 
their indigenous knowledge concerning the breed during the field work.

\section{Conflicts of Interest}

The authors declare no conflicts of interest regarding the publication of this paper.

\section{References}

[1] Central Statistics Agency (2017) Agricultural Sample Survey 2016/17. Volume II Report on Livestock and Livestock Characteristics (Private Peasant Holdings), Central Statistical Agency, Addis Ababa, 188 p.

[2] Mourad, R., Aynalem, H., Zeleke, M., Ayele, S. and Barbara, R. (2008) Review of the Reproductive Performances of Sheep Breeds in Ethiopia. ICARDA, Beirut, p. 23.

[3] Kosgey, I.S., Rowlands, G.J., van Arendonk, J.A.M. and Baker, R.L. (2006) Small Ruminant Production in Smallholder and Pastoral/Extensive Farming Systems in Kenya: A Review. Small Ruminant Research, 61, 64-73.

[4] Gebrehiwot, T. and Van der Veen, A. (2013) Assessing the Evidence of Climate Variability in the Northern Part of Ethiopia. Journal of Development and Agricultural Economics, 5, 104-119.

[5] Workneh, A., Van Dorland, A. and Rowland, J. (2004) Design, Extention and Analysis of Livestock Breed Survey in Oromiya Regional State, Ethiopia. OADB (Ormoiya Agricultural Development Bureau), Addis Ababa, Ethiopia and ILRI (International Livestock Research Institute), Nairobi, 260 p.

[6] SPSS (Statistical Package for Social Science) (2012) International Businesses machines of Statistical Package for Social Sciences Statistics for Windows, Version 21.0. IBM Corp., Armonk, NY.

[7] SAS (Statistical Analysis System) (2008) SAS/STAT Guide to Personal Computers, Version 9th Edition, Prentice Hall, London, 245-477.

[8] Kosgey, I.S. and Okeyo, A.M. (2004) Genetic Improvement of Small Ruminants in Low-Input, Small Holder Production Systems: Technical and Infrastructural Issues. Small Ruminant Research, 70, 76-88. https://doi.org/10.1016/j.smallrumres.2007.01.007

[9] Institute of Biodiversity Conservation (2004) The State of Ethiopia's Farm Animal Genetic Resources: Country Report. A Contribution to the First Report on the Stat of the World's Animal Genetic Resources. IBC, May 2004, Addis Ababa.

[10] Admasu, L., Aberra, M. and Banerjee, S. (2017) Traditional Sheep Production Systems and Breeding Practice in Wolayita Zone of Southern Ethiopia. African Journal of Agricultural Research, 12, 1689-1701.

[11] Weldeyesus, G., Yaynishet, T. and Zelealem, T. (2016) Management and Breeding Objectives of Indigenous Smallholder Highland Sheep in Northern Ethiopia. Journal of Biology, Agriculture and Healthcare, 6, 96-106.

[12] Central Statistics Agency (2017) Ethiopian National Population and Housing Census. Central Statistical Agency, Addis Ababa, 385 p.

[13] Abebe, M. (1999) Husbandry Practice and Productivity of Sheep in Lalo-Mama Midirworeda of Central Ethiopia. M.Sc. Thesis, Alemaya University of Agriculture, Dire Dawa.

[14] Abegaz, S., Hegde, B.P. and Taye, M. (2011) Growth and Physical Body Characteristics of Gumuz Sheep under Traditional Management Systems in Amhara Regional State, Ethiopia. 
[15] Mengistie, T., Girma, A., Solomon, G., Sisay, L., Abebe, M. and Markos, T. (2010) Traditional Management Systems and Linear Body Measurements of Washera Sheep in the Western Highlands of the Amhara National Regional State, Ethiopia. Livestock Research for Rural Development.

[16] Gizaw, S., van Arendonk, J.A.M., Valle-Zarate, Aynalem, H., Rischkowsky, B., Taddle, D. and Mwai, A.O. (2014) Breeding Programmes for Smallholder Sheep Farming Systems: Optimization of Cooperative Village Breeding Schemes. Journal of Animal Breeding and Genetics, 131, 350-357. https://doi.org/10.1111/jbg.12102

[17] Behnke, H. and Scoones, I. (1993) Rethinking Range Ecology: Implications for Rangeland.

[18] Zelealem, T.G. and Anal, A.K. (2014) Indigenous Sheep Breeds of North Ethiopia: Characterization of Their Phenotype and Major Production System. Tropical Animal Health and Production, 46, 341-347. https://doi.org/10.1007/s11250-013-0494-0

[19] Sibut, V., Le Bihan-Duval, S., Tesseraud, E., Godet, T., Bordeau, E., Cailleau-Audouin, P., Chartrin, M.J., Duclos and Berri, C. (2008) Adenosine Monophosphate-Activated Protein Kinase Involved in Variations of Muscle Glycogen and Breast Meat Quality between Lean and Fat Chickens. Journal of Animal Science, 86, 2888-2896. https://doi.org/10.2527/jas.2008-1062

[20] Jaitner, J., Sowe, J., Secka-Njie, E. and Dempfle, L. (2001) Ownership Pattern and Management Practices of Small Ruminants in the Gambia-Implications for a Breeding Programme. Small Ruminant Research, 40, 101-108. https://doi.org/10.1016/S0921-4488(00)00221-2

[21] Jimmy, S., David, M., Donald, K.R. and Dennis, M. (2010) Smallholder Goat Breeding Systems in Humid, Sub-Humid and Semi-Arid Agro-Ecological Zones of Uganda. Global Veterinarian, 4, 283-291.

[22] Falconer, D.S. (1989) Introduction to Quantitative Genetics. 3rd Edition, Longman Scientific and Technical, New York.

[23] Ndamukong, K.J., Sewell, M.M. and Asanji, M.F. (1989) Management and Productivity of Small Ruminants in Northwest Province of Cameroon. Tropical Animal Health and Production, 21, 109-119. https://doi.org/10.1007/BF02236189

[24] Tesfaye, G., Aynalam, H., Markos, T., Sharama, A.K. and Solkner, J.M. (2010) Herd Management and Breeding Practices of Sheep Owners in a Mixed Crop-Livestock and a Pastoral System of Ethiopia. African Journal of Agricultural Research, 5, 685-691.

[25] Mukasa-Mugerwa, E. and Lahlou-Kassi, A. (1995) Reproductive Performance and Productivity of Menz Sheep in the Ethiopian Highlands. Small Ruminant Research, 17, 167-177.

[26] Edea, Z., Haile, A., Tibbo, M., Sharma, A.K., Solkner, J. and Wurzinger, M. (2012) Sheep Production Systems and Breeding Practices of Smallholders in Western and Southwest Ethiopia. Implications for Designing Community-Based Breeding Strategies. Yabello Pastoral and Dryland Agriculture Research Centre.

[27] Helen, N., Solomon, A., Yoseph, M. and Kefelge, K. (2015) Indigenous Sheep Production System in Eastern Ethiopia: Implications for Genetic Improvement and Sustainable Use. American Scientific Research Journal for Engineering, Technology, and Sciences, 11, 136-152.

[28] Tembely, S. (1998) Small Ruminant Production in Ethiopia Prospects for Improving Productivity. Proceeding of 5th Conference of ESAP, Addis Ababa, 15-17 May 
1997, 82-90.

[29] Abegaz, S., Hegde, H.P. and Taye, M. (2011) Growth and Physical Body Characteristics of Gumuz Sheep under Traditional Management Systems in Amhara Regional State, Ethiopia. Livestock Research for Rural Development, 23, 1-5.

[30] Zewudu, E. (2008) Characterization of Bonga and Horro Indigenous Sheep Breeds of Smallholders for Designing Community Based Breeding Strategies in Ethiopia. M.Sc. Thesis, School of Graduate Studies of Haramaya University, Dire Dawa.

[31] Ayele, S., Assegid, W., Jabbar, M.A., Ahmed, M.M. and Belachew, H. (2003) Livestock Marketing in Ethiopia: A Review of Structure, Performance and Development Initiatives. International Livestock Research Institution (ILRI) Socio-Economics and Policy Research Working Paper 52.

[32] Gezahegn, A., Mohammad, A.J., Hailemariam, T., Elias, M. and Getahun, K. (2003) Seasonal and Inter-Market Differences in Prices of Small Ruminants in Ethiopia. Journal of Food Products Marketing, 12, 59-77. 